\section{Sleep problems in 0-36 months old Indonesian children with atopic dermatitis}

\author{
Irwanto, Hapsari W. Ningtiar, Taufiq \\ Hidayat, Azwin M. Putera, Zahrah \\ Hikmah, Anang Endaryanto \\ Department of Child Health, Faculty of \\ Medicine, Airlangga University/Dr. \\ Soetomo General Hospital, Surabaya, \\ Indonesia
}

\begin{abstract}
Atopic dermatitis (AD) is a chronic, relapsing, highly pruritic skin condition that develops in early childhood. Sleep problems are common in $\mathrm{AD}$ children and lead to impaired quality of life, disturbance of neurocognitive function and behavior. The aim of this study was to assess the prevalence of sleep problems in 0-36 months old Indonesian children with AD. Children aged 0-36 months were enrolled, divided into two groups, AD and control. Sleep problems and $\mathrm{AD}$ were assessed using Brief Infant Sleep Questionnaire (BISQ) and Severity Scoring of Atopic Dermatitis Index (SCORAD). Chi-square test was performed to compare the outcome. There were 35 children participating in each group. In children with sleep problems, $85.7 \%$ were diagnosed with $\mathrm{AD}$ and $11.4 \%$ were non-AD. Nocturnal sleep duration, night waking, nocturnal wakefulness, sleep onset time, method of falling asleep and parental consideration of sleep problems occur more often within $\mathrm{AD}$ group. Severity of AD also significantly contributes to sleep problems in $\mathrm{AD}$ group. In conclusion, this study showed that sleep problems are more prevalent in children with $\mathrm{AD}$.
\end{abstract}

\section{Introduction}

Atopic dermatitis (AD) is a common chronically relapsing pruritic inflammatory skin disease. AD is a complex disease with a genetic predisposition strongly influenced by innate and adaptive immune responses. ${ }^{1-}$ ${ }^{3}$ Sleep problems in children with $\mathrm{AD}$ is a serious issue because sleep plays an important role in promoting physical and mental health. Sleeping patterns mostly develop in the first year of an infant's lifespan. It is suggested that about $20-30 \%$ of children may have sleeping problems in their first 3 years of life and it maybe relate to the behavioral pattern at noon and familial/parental problem. Many sleep problems are associated with problems of cognitive functioning, learning, attention and school performance. ${ }^{4-7}$ The prevalence of sleep problems in children with $\mathrm{AD}$ is approximately range from $47 \%$ to $60 \%$ and appear especially during infancy to preschool age. ${ }^{8,9}$ Despite the widespread prevalence of sleep disruption in children with $\mathrm{AD}$, the mechanism of this disruption is poorly understood. ${ }^{8-10}$

It is recommended that clinician should ask general questions about itch, sleep, impact on daily activity, and persistence of disease using disease severity during practical. A variety of measurement tools are utilized in sleep assessment, including Electroencephalography (EEG), Polysomnography, Actigraphy and Brief Infant Sleep Questionnaire (BISQ). The BISQ is used to screen sleep problems. The Severity Scoring of Atopic Dermatitis Index (SCORAD) is commonly used to determine the severity of $\mathrm{AD}$, can also be used to determine subjective patient assessment of itch and sleep loss. ${ }^{11,12}$ This study investigates the prevalence of sleep problems in children with AD in Indonesia.

\section{Materials and Methods}

\section{Methods}

A cross sectional study was conducted in Surabaya and Sidoarjo, Indonesia on September $1^{\text {st }}$ to October $31^{\text {st }}$ 2017. The sample of this study was 70 children who consisted of 35 children with AD and 35 children with no AD. Sample size was calculated based on the total sampling. Children enrolled in the study met the following criteria: age between 0 and 36 months old who had $\mathrm{AD}$ for 3 months before the study began and did not have $\mathrm{AD}$, stable medical conditions, and no change in medication related to sleep or health status in the past 3 months. Diagnosis of AD based on history and physical examination. ${ }^{11}$ Researcher interviewed the parents/caregivers and completed a BISQ after the parents were being informed of the study and gave their written consents. Weight measurement was taken for all the children and plotted in the WHO growth chart to determine the nutritional status (weight for age). Data then were presented as a distribution and percentage of each variable referring to the BISQ and nutritional status. Analysis of AD relationship to sleep problems used chi-square, with significant test with $95 \%$ confidence interval and SPSS 17.0 performed it. This study was approved by the Ethics Committee of
Correspondence: Irwanto, Department of Child Health, Faculty of Medicine, Airlangga University/Dr. Soetomo General Hospital, Surabaya, Cosmopolis Resort B-19, Jl Arief Rahman Hakim 147 Surabaya 60111, Indonesia.

Tel: +62816500818 - Fax: +62315022472.

E-mail: Irwanto.idris@gmail.com

Key words: Sleep problem; Atopic Dermatitis; Sleep questionnaire.

Acknowledgements: The authors wish to thank Director of Dr Soetomo Hospital, Husada Utama Hospital Surabaya, and H.M Mawardi Hospital, Sidoarjo, Indonesia for their support of the field investigation.

Contributions: I: First Author Correspondence Author; Substantial contributions to the conception or design of the work; or the acquisition, analysis, or interpretation of data for the work; Drafting the work or revising it critically for important intellectual content; Final approval of the version to be published; Agreement to be accountable for all aspects of the work in ensuring that questions related to the accuracy or integrity of any part of the work are appropriately investigated and resolved. HWN: co-author; Contributions to data recapitulation; Helping analysis of the data. TH, AMP, ZH, AE: co-authors; Sample gathering of child with Atopic dermatitis in affiliated hospitals; Ensuring the process of sample gathering until data processing.

Conflict of interest: The authors declare no potential conflict of interest.

Received for publication: 1 February 2019. Accepted for publication: 11 February 2019.

This work is licensed under a Creative Commons Attribution-NonCommercial 4.0 International License (CC BY-NC 4.0).

(C) Copyright Irwanto et al., 2019

Licensee PAGEPress, Italy

Dermatology Reports 2019; 11(s1):8039

doi:10.4081/dr.2019.8039

Soetomo Hospital/Faculty of Medicine, Airlangga University, Surabaya, Indonesia.

\section{Materials}

The Brief Infant Sleep Questionnaire (BISQ) was used to assess the sleep problems. These questionnaires were attained primarily by retrospective method with the parents/caregivers recalling on sleep patterns, disturbances, or behaviors (e.g., sleeping arrangement, preferred body position during sleep, nocturnal sleep duration, daytime sleep duration, number of night waking, duration of wakefulness during the night hours (10 pm-6 am), settling time, method of falling asleep, nocturnal sleep- 
onset duration, parenteral consideration of sleep problem). Sleep problems were defined as the presence of one or more of the following conditions, such as less than 9 hours of nocturnal sleep duration, more than 3 times of night waking, and more than 1 hour of duration of wakefulness. ${ }^{13}$ Degree of severity of $\mathrm{AD}$ is based on SCORAD index. ${ }^{14}$ Anthropometry assessment is based on WHO Growth chart. ${ }^{15}$

\section{Results}

There were seventy 0-36 months old children who participated in this study and divided into 2 groups, 35 children with AD and 35 children without AD.

\section{Distribution (Table 1) II. Brief Infant Sleep Questionnaire (BISQ)}

Sleep measurements in both groups showed significant results in nocturnal sleep duration, night waking, nocturnal wakefulness, sleep onset time, method of falling asleep and parental consideration of sleep problems (Table 2).

Based on BISQ, the prevalence of sleep problems for children with $\mathrm{AD}$ was $85.7 \%$ and $11.4 \%$ children without AD respectively (Table 3 ).

\section{Discussion}

This study has found that among children with sleep problems, $85.7 \%$ was reported suffering AD and only $11.4 \%$ children were without AD. The prevalence of children with AD in our study $(85.7 \%)$ was higher than other studies that found sleep problems in children with $\mathrm{AD}$, with rates ranging from $47 \%$ to $60 \%$ and appear especially during infancy to pre-school age. ${ }^{8,9}$ Diagnosis of sleep problems in this study based on nocturnal sleep duration less than 9 hours, children waking up at night more than 3 times, and nocturnal wakefulness for more than one hour. In our study, cause of sleep problems was pruritus and scratching. It is also worth noting that sleep near parents was a factor for sleep problems according to BISQ, in which usually practiced by Indonesian parents. ${ }^{16,17}$

There were significant differences for nocturnal sleep duration, night waking, nocturnal wakefulness, sleep onset time, method of falling asleep and parental consideration of sleep problems in children with $\mathrm{AD}$ compared to children without AD based on Brief Infant Sleep Questionnaire
Table 1. Characteristic of children with/out $\mathrm{AD}(\mathrm{N}=70)$.

\begin{tabular}{|c|c|c|}
\hline Participants & $\begin{array}{c}\text { Children with AD } \\
\qquad(\mathrm{N}=35)\end{array}$ & $\begin{array}{l}\text { Children without AD } \\
\qquad(\mathrm{N}=35)\end{array}$ \\
\hline Age (months) Mean \pm SD (range) & $17 \pm 10$ & $19 \pm 10$ \\
\hline $\begin{array}{r}\text { Gender } \\
\text { Boy } \\
\text { Girl }\end{array}$ & $\begin{array}{l}16 \\
19\end{array}$ & $\begin{array}{l}16 \\
19\end{array}$ \\
\hline $\begin{array}{l}\text { Anthropometry (Weight for Age) } \\
\text { Severely underweight } \\
\text { Underweight } \\
\text { Median } \\
\text { Overweight } \\
\text { Obesity }\end{array}$ & $\begin{array}{c}0 \\
4 \\
31 \\
0 \\
0\end{array}$ & $\begin{array}{c}0 \\
8 \\
27 \\
0\end{array}$ \\
\hline $\begin{array}{l}\text { Family history of Atopy } \\
\text { Yes } \\
\text { No }\end{array}$ & $\begin{array}{l}23 \\
12\end{array}$ & $\begin{array}{l}17 \\
18\end{array}$ \\
\hline $\begin{array}{l}\text { Birth order of the child } \\
\text { Oldest } \\
\text { Middle } \\
\text { Youngest }\end{array}$ & $\begin{array}{l}15 \\
4 \\
16\end{array}$ & $\begin{array}{c}14 \\
3 \\
10\end{array}$ \\
\hline $\begin{array}{l}\text { SCORAD Index } \\
\text { Mild } \\
\text { Moderate } \\
\text { Severe }\end{array}$ & $\begin{array}{c}25 \\
10 \\
0\end{array}$ & $\begin{array}{l}0 \\
0 \\
0\end{array}$ \\
\hline
\end{tabular}

Table 2. Brief Infant Sleep Questionnaire (BISQ) in children 0-36 months old.

\begin{tabular}{|c|c|c|c|}
\hline & $\begin{array}{c}\text { Group } \\
\text { AD (+) } \\
\text { N (\%) }\end{array}$ & $\begin{array}{c}\text { P } \\
\text { AD (-) } \\
\text { N (\%) }\end{array}$ & \\
\hline $\begin{array}{l}\text { Nocturnal sleep duratic } \\
\quad<9 \text { hours } \\
\quad \geq 9 \text { hours }\end{array}$ & $\begin{array}{c}30(85.7) \\
5(14.3)\end{array}$ & $\begin{array}{c}4(11.4) \\
31(88.6)\end{array}$ & $*$ \\
\hline $\begin{array}{l}\text { Daytime sleep duration } \\
<9 \text { hours } \\
\geq 9 \text { hours }\end{array}$ & $\begin{array}{c}28(80) \\
7(20)\end{array}$ & $\begin{array}{c}33(94.3) \\
2(5.7)\end{array}$ & NS \\
\hline $\begin{array}{l}\text { Night waking } \\
\geq 3 \text { times } \\
<3 \text { times }\end{array}$ & $\begin{array}{l}25(71.4) \\
10(28.6)\end{array}$ & $\begin{array}{c}2(5.7) \\
33(94.3)\end{array}$ & $*$ \\
\hline $\begin{array}{l}\text { Nocturnal wakefulness } \\
\quad \geq 1 \text { hour } \\
<1 \text { hour }\end{array}$ & $\begin{array}{c}9(25.7) \\
26(74.3)\end{array}$ & $\begin{array}{c}0 \\
35(100)\end{array}$ & $*$ \\
\hline $\begin{array}{l}\text { Sleep onset time } \\
\quad<30 \text { minutes } \\
\geq 30 \text { minutes }\end{array}$ & $\begin{array}{l}17(48.6) \\
18(51.4)\end{array}$ & $\begin{array}{c}31(88.6) \\
4(11.4)\end{array}$ & $*$ \\
\hline $\begin{array}{l}\text { Method of falling aslee } \\
\text { Feeding } \\
\text { In bed alone } \\
\text { Being rocked } \\
\text { In bed near parent } \\
\text { Being held }\end{array}$ & $\begin{array}{c}2(5.7) \\
4(11.4) \\
1(2.9) \\
10(28.6) \\
18(51.4)\end{array}$ & $\begin{array}{c}13(37.1) \\
9(25.7) \\
0(0) \\
9(25.7) \\
4(11.4)\end{array}$ & $*$ \\
\hline $\begin{array}{l}\text { Settling time } \\
\quad \geq 8 \mathrm{pm} \\
\quad<8 \mathrm{pm}\end{array}$ & $\begin{array}{c}7(20) \\
28(80)\end{array}$ & $\begin{array}{l}10(28.6) \\
25(71.4)\end{array}$ & NS \\
\hline $\begin{array}{l}\text { Parental consideration } \\
\text { Serious problem } \\
\text { Small problem } \\
\text { No problem }\end{array}$ & $\begin{array}{l}\text { lem } \\
10(28.6) \\
9(25.7) \\
16(45.7)\end{array}$ & $\begin{array}{c}0(0) \\
7(20) \\
28(80)\end{array}$ & $*$ \\
\hline
\end{tabular}

${ }^{*} \mathrm{P}<0.05$ (Chi-Square test); NS: Non significant.

Table 3. Children with $\mathrm{AD}$ who had sleep problems

\begin{tabular}{lccc} 
Sleep Problems & Children with AD & Children without AD & P \\
Yes & $30(85.7)$ & $4(11.4)$ & $0.001^{*}$ \\
No & $5(14.3)$ & $31(88.6)$ & $0.001^{*}$ \\
\hline
\end{tabular}

*Significant (Chi-Square test). 
(BISQ). Our study also found that majority of daytime and nocturnal sleep duration in children with $\mathrm{AD}$ is less than 9 hours, which is similar with study by Dogan (2017) that found children with AD did not have decrease daily total sleep duration. ${ }^{8}$ However, several studies found that sleep duration was significantly reduced in infants with severe AD. ${ }^{8,9,18}$ Pathophysiology of sleep problems in children with $\mathrm{AD}$ is still not fully understood. Circadian rhythm of cytokines, immune system, melatonin, and skin physiology such as transcutaneous water loss and skin blood flow might play a role. ${ }^{9}$ The sleeping problems which mostly happens in children were reported had relation with the frequency of waking up at night and their sleep onset time. ${ }^{18}$ However, this study has found that children with $\mathrm{AD}$ have generally longer afternoon naptime compared with non-AD children, although with a higher frequency of waking up during naptime. We also found that severity of $\mathrm{AD}$ in this study is based on SCORAD Index showed association to sleep problems in AD group. This suggests that severity of $\mathrm{AD}$ may reflect the severity of sleep problems itself.

Adequate sleeping is important in maintaining children's health and development. However, sleeping problems may affect negatively towards the quality of life of the patients, their cognitive function, behavioral patterns, and shifting of moods. It is suggested that AD may have an association with attention deficit hyperactivity disorder, behavioral problems and conduction and short-term self-control only if it is related with sleeping problems.

Finally, we conclude that there was higher prevalence of sleep problems within children with AD compared to normal children. Without good sleep quality, children with $\mathrm{AD}$ may have poorer quality of life compared to normal children. Therefore, a thorough examination, proper diagnosis, adequate $\mathrm{AD}$ control, and comprehensive $\mathrm{AD}$ complication management need to be provided to ensure good quality of life in children with $\mathrm{AD}$.

\section{References}

1. Bieber T. Atopic Dermatitis. Ann Dermatol 2010;22(2):125-37.

2. Leung DY, Guttman-Yassky E. Deciphering the complexities of atopic dermatitis: Shifting paradigms in treatment approaches. J. Allergy Clin. Immunol 2014;134:769-79.

3. Thomsen SF. Epidemiology and natural history of atopic diseases. Eur Clin Respir J 2015;2:10.3402/ecrj.v2.24642.

4. Bathory E, Tomopoulus S. Sleep regulation, physiology and development, sleep duration and patterns, and sleep hygiene in infant, toddlers, and preschool-age children. Curr Probl Pediatr Adolesc Health Care 2017;47:29-42.

5. Allen S, Howlett M, Coulombe J and Corkum P. ABCs of sleeping: a review of the evidence behind pediatric sleep practice recommendation. Sleep Med Rev 2016;29:1-14.

6. Sadeh, A, Gruber R, Raviv A. Sleep, neurobehavioral functioning, and behavior problems in school-age children. Child Dev 2002;73(2):405-17.

7. Gregory A, Sadeh A. Sleep, emotional and behavioral difficulties in children and adolescents. Sleep Med Rev 2012; 16(2):129-36.

8. Dogan DG, Canaloglu SK, Kivilcim M, et al. Sleep patterns of young children with newly diagnosed atopic dermatitis. Postepy Dermatol Alergol 2017;34(2): 143-47.

9. Chang YS, Chiang BL. Mechanism of Sleep Disturbance in Children with Atopic Dermatitis and the Role of the Circadian Rhythm and Melatonin. Int J Mol Sci 2016;17:462.

10. Chang YS. Atopic Dermatitis, Melatonin, and Sleep Disturbance.
Pediatrics 2014;134:e397-405.

11. Eichenfield LF, Tom WL, Chamlin SL, et al. Guidelines of care for the management of atopic dermatitis: Section 1 . Diagnosis and assessment of atopic dermatitis. J Am Acad Dermatol 2014; 70:338-51.

12. Oranje AP, Glazenburg EJ, Wolkerstorfer A, de Waard-van der Spek FB. Practical issues on interpretation of scoring atopic dermatitis: the SCORAD index, objective SCORAD and the three-item severity score. Br J Dermatol 2007; 157:645-8.

13. Sadeh A. A Brief Screening Questionnaire for Infant Sleep Problems: Validation and Findings for an Internet Sample. Pediatrics 2004;113:e570-e7.

14. Severity Scoring of Atopic Dermatitis Index (SCORAD) [cited 2017 August 1]. Available from: http://apps.centralpho.org.nz/Permalink/MoM/Genera 1\%20Documents/MoM/Published/Child $\% 20$ Health/Eczema/Severity $\% 20$ Scori ng\%20of\%20Atopic\%20Dermatitis $\% 2$ 0Index\%20SCORAD.pdf

15. WHO. Child growth standards Weight for age [cited 2017 August 1]. Available from: http://www.who.int/childgrowth/standards/weight_for_age/en/

16. Sadeh, A, Mindell JA, Luedtke K, Wiegand B. Sleep and sleep ecology in the first 3 years: a web-based study. J Sleep Res 2009;18(1):60-73.

17. Chamlin SL, Mattson CL, Frieden IJ, et al. The price of pruritus: sleep disturbance and cosleeping in atopic dermatitis. Arch Pediatr Adolesc Med 2005;159(8):745-50.

18. Anuntaseree W, Sangsupawanich P, Osmond C, et al. Sleep quality in infants with atopic dermatitis: a community-based, birth cohort study. Asian Pac J Allergy Immunol 2012;30(1):2631. 